\title{
Seasonal variations in the level of mutagenicity: an assessment of respirable particulate matter in Rio de Janeiro, Brazil
}

\author{
C. R. Rainho ${ }^{1}$, S. M. Corrêa ${ }^{2}$, J. L. Mazzei ${ }^{3}$, C. A. F. Aiub ${ }^{4}$ \\ \& I. Felzenszwalb ${ }^{1}$ \\ ${ }^{I}$ Department of Biophysics and Biometry, \\ State University of Rio de Janeiro, Brazil \\ ${ }^{2}$ Department of Environmental Chemistry, \\ State University of Rio de Janeiro, Brazil \\ ${ }^{3}$ Farmanguinhos Platform for Analytical Methods, \\ Fundação Oswaldo Cruz, Brazil \\ ${ }^{4}$ Department of Genetics and Molecular Biology, \\ Federal University of the State of Rio de Janeiro, Brazil
}

\begin{abstract}
Respirable particles (PM2.5) can become associated with organic matter containing several compounds such as polycyclic aromatic hydrocarbons (PAHs). Many PAHs have been identified as cancer-inducing chemicals. The mutagenicity of airborne particles is generally associated with PAHs, but recent reviews show that PAHs may not be the predominant mutagens in atmospheric pollution, and that nitroaromatic compounds, aromatic amines and aromatic ketones, often found in moderately polar or highly polar organic fractions, are potent mutagens. Nitro-polycyclicaromatics (nitro-PAHs) are persistent environmental mutagens and can be found in airborne suspended particles from direct sources such as diesel and gasoline exhausts, or may be products of atmospheric reactions in the presence of $\mathrm{NO}_{2}$ and $\mathrm{NO}_{3}$ radicals. In the present work we compared PAH levels and mutagenicity using gas chromatography spectrometry and the Salmonella/microsome assay on organic extracts of PM2.5 for Salmonella typhimurium strain TA98. The samples were collected in two periods: (I) July to October 2010 and (II) November 2010 to May 2011 at three sites in Rio de Janeiro - (1) low urban traffic at the University campus; (2) heavy
\end{abstract}


urban traffic at Brasil Avenue and (3) Rebouças tunnel. We also performed measurements of nitro-PAH levels for November 2010 to May 2011. For both periods, site 3 showed the highest concentrations of PAHs and nitro-PAHs. Period I showed the higher values of rev $/ \mathrm{m}^{3}$. Mutagenic frameshift responses in the absence of metabolic activation were detected at all the sites in periods I and II. In the presence of metabolic activation this response was observed for all three sites in period I, but only for site 3 in period II. Nitroarenes and dinitroarenes were detected at all three sites in period I. In period II, the presence of nitroarenes was also detected at all sites, but dinitroarenes were only detected at sites 2 and 3. The information generated in this study shows that different levels of PAHs and nitroderivatives, influenced by seasonal variations in climatic conditions, probably contribute to the detected airborne mutagenicity.

Keywords: seasonal variations, mutagenicity assessment, respirable particulate matter, polycyclic aromatic hydrocarbons, nitro-polycyclicaromatics.

\section{Introduction}

Respirable particles $\leq 2.5 \mu \mathrm{m}$ (PM2.5) originating from motor vehicle exhaust fumes are a major source of particulate matter, with potentially serious health impacts [1]. These pollutants can become associated with organic matter containing several compounds, such as polycyclic aromatic hydrocarbons (PAHs) [2]. Many PAHs have been identified as cancer-inducing chemicals [2]. Recent reviews show that PAHs are not the predominant mutagens in atmospheric pollution. Nitroaromatic compounds, aromatic amines and aromatic ketones, often found in moderately polar or highly polar fractions, are potent mutagens [3,4]. Nitro-polycyclicaromatics (nitro-PAHs) are persistent environmental mutagens and can be found in suspended airborne particles from direct sources such as diesel and gasoline exhaust fumes, or may be products of atmospheric reactions in the presence of $\mathrm{NO}_{2}$ and $\mathrm{NO}_{3}$ radicals [4-6].

In Rio de Janeiro, climatic conditions vary during the year, with precipitation occurring mainly between the months of December and March (rainy season) and scarcely at all in July and August (dry season) [7]. Critical air pollutants, such as PAHs and PM, increase during the dry season and decrease during the rainy season [8]. In 2010, we conducted a monitoring study at three sites of the city of Rio de Janeiro: the campus of the Rio de Janeiro State University, Avenida Brasil and Rebouças tunnel $[9,10]$. In these studies we detected values for PM2.5 that exceeded the values established by the World Health Organization [11] at all three sites. Furthermore, mutagenicity was detected in the organic extract of PM2.5 for Salmonella typhimurium strain TA98 and derivatives with sensitivity to nitro compounds [9, 10].

To study the influence of seasonal variations on the mutagenic activity of PM samples, we analyzed samples collected between November 2010 and May 2011 at the same sites and compared them with the data from our previous studies $[9,10]$. 


\section{Materials and methods}

\subsection{Sampling sites}

The samples were collected at three sites in Rio de Janeiro: the campus of the Rio de Janeiro State University (site 1), Avenida Brasil (site 2) and Rebouças tunnel (site 3) between November 2010 and May 2011 (Period II). Site 1, with low traffic, is located in a residential area of the city's north zone. Site 2 has heavy traffic ( $\sim 250,000$ vehicles/day) and is the city's biggest highway, covering $58 \mathrm{~km}$ in length and crossing 27 neighborhoods. Site 3 has heavy traffic $(\sim 190,000$ vehicles/day). It connects the north and south zones of the city and is $2.8 \mathrm{~km}$ long $[9,10]$.

Airborne PM2.5 samples were collected on fiberglass filters (E558 X 10IN, $254 \mathrm{~mm} \times 203 \mathrm{~mm}$ ) using a high-volume collector (AVG MP 2.5, $1.13 \mathrm{~m}^{3} / \mathrm{mim}$ ) for $24 \mathrm{~h}$ at sites 1 and 2 , and $6 \mathrm{~h}$ at site 3 . Four monthly samplings were performed for each site. The filters were weighed and stabilized before and after samples ( $45 \%$ humidity) for the determination of particulate concentration, expressed in $\mu \mathrm{g} / \mathrm{m}^{3}$ units of sampled air [12-14]. At the end of the sampling, the filters were combined to form a pool sample.

\subsection{Extraction of organic compounds}

Half of each filter was sonicated in three rounds of $10 \mathrm{~min}$ each using dichloromethane (DCM, CASRN. 75-09-2, Tedia Brazil, Brazil, purity 99.9\%). The extracts were concentrated to $15 \mathrm{~mL}$ in a rotating evaporator and filtered in a Teflon membrane $(0.5 \mu \mathrm{m})$. The concentration of extractable organic matter (EOM, in $\mu \mathrm{g} / \mathrm{m}^{3}$ ) was calculated. Prior to bioassays, the organic extract was dried at $4^{\circ} \mathrm{C}$ and resuspended in $5 \mu$ dimethyl sulfoxide (DMSO, CASRN. 6768-5, Synth, Brazil, purity 99.9\%) [12-14].

\subsection{Analysis of polycyclic aromatic hydrocarbons (PAHs)}

PAHs were identified and quantified by gas chromatography/mass spectrometry (GC/MS) using a Varian system consisting of a gas chromatograph (450-GC) with a split/splitless injector $1177 \mathrm{~S} / \mathrm{SL}$ (kept at $300^{\circ} \mathrm{C}$ ) coupled to the mass spectrometer detector (MS 220). The ion trap $\left(250^{\circ} \mathrm{C}\right)$, manifold $\left(280^{\circ} \mathrm{C}\right)$ and transfer line $\left(280^{\circ} \mathrm{C}\right)$ were maintained at constant temperatures. PAHs were identified by mass similarity and by the retention time of the components in a commercial standard kit (Supelco, PAH610-S). Quantification was based on five calibration points, which were constructed from each standard for all the target analytes, ranging from 10 to $250 \mathrm{pg} / \mu \mathrm{L}$. Injections $(2.0 \mu \mathrm{L})$ were splitless, with the split opened after $0.5 \mathrm{~min}$, and helium 5.0 was used as the carrier gas. A VF$5 \mathrm{MS}$ column $(30 \mathrm{~m} \times 0.25 \mathrm{~mm} \times 0.25 \mu \mathrm{m})$ was employed. The column and septum purge flows were set at 1.6 and $3 \mathrm{~mL} / \mathrm{min}$, respectively. The oven temperature program was as follows: $70^{\circ} \mathrm{C}$ for 4 min then heating to $300^{\circ} \mathrm{C}$ at $10^{\circ} \mathrm{C} / \mathrm{min}$. This procedure was designed for the analysis of the 16 priority PAHs, but only six were detected: phenanthrene, fluoranthene, pyrene, benzo[a]anthracene, chrysene and benzo[a]pyrene. The limits of quantification 
were determined from the minimum point in the calibration curves. Limits of detection were determined from PAH concentrations, which resulted in a signalto-noise ratio of $3: 1$. The results were expressed in $\mathrm{ng} / \mathrm{m}^{3}$ [15].

\subsection{Analysis of nitro-polycyclic aromatic hydrocarbons (nitro-PAHs)}

Nitro-PAHs were identified and quantified by GC/MS using a Varian system consisting of a gas chromatograph (450-GC) with a Programmed Temperature Vaporization Injector 1079 (PTV) starting at $75^{\circ} \mathrm{C}$ for $0.2 \mathrm{~min}$ then heated at $200^{\circ} \mathrm{C} /$ min until $340^{\circ} \mathrm{C}$. The mass spectrometer detector (MS 220) was operated under the following conditions: ion trap $\left(250^{\circ} \mathrm{C}\right)$, manifold $\left(280^{\circ} \mathrm{C}\right)$ and transfer line $\left(280^{\circ} \mathrm{C}\right)$ were maintained at constant temperatures. Nitro-PAHs were identified by mass similarity and by the retention time of the components in a commercial standard kit (Supelco, PAH610-S). Quantification was based on five calibration points in duplicate, which were constructed from each standard for all the target analytes, ranging from 25 to $400 \mathrm{ppb}$. Injections $(50 \mu \mathrm{L})$ were splitless, with the split opened after $0.5 \mathrm{~min}$, and helium 5.0 was used as the carrier gas at a constant flow of $1.2 \mathrm{~mL} / \mathrm{min}$. A VF-5MS column $(30 \mathrm{~m} \times 0.25 \mathrm{~mm} \times 0.25 \mu \mathrm{m})$ was employed. The oven temperature program was as follows: $70^{\circ} \mathrm{C}$ for $2 \mathrm{~min}$ then heating to $210^{\circ} \mathrm{C}$ at $10^{\circ} \mathrm{C} / \mathrm{min}$, then heating to $300^{\circ} \mathrm{C}$ at $20^{\circ} \mathrm{C} / \mathrm{min}$. This procedure was designed for the analysis of 13 nitro-PAHs: nitro-naphthalene, nitro-acenaphthylene, nitro-acenaphthene, nitro-fluorene, nitro-phenanthrene, nitro-anthracene, nitro-fluoranthene, nitro-pyrene, nitro-benzo[a]anthracene, nitro-chrysene, nitro-benzo[b]fluoranthene, nitro-benzo[k]fluoranthene and nitrobenzo[a]pyrene. The limits of quantification were determined from the minimum point in the calibration curves. Limits of detection were determined from nitroPAH concentrations, which resulted in a signal-to-noise ratio of $3: 1$. The results were expressed in $\mathrm{ng} / \mathrm{m}^{3}$.

\subsection{Salmonella/microsome assay}

The organic extracts were assayed for mutagenicity using the microsuspension version [16] of the Salmonella/microsome assay [17]. Salmonella typhimurium TA98 (frameshift strain) and the derivative strains YG1021 (nitroreductaseoverproducing) and YG1024 ( $O$-acetyltransferase-overproducing) [18] were used, with and without metabolic activation ( $\mathrm{S} 9 \mathrm{mix}$ fraction). Five concentrations of each sample $(10,20,30,40$ and $50 \mu \mathrm{g} / \mathrm{plate})$ were tested in triplicate. The samples were pre-incubated for $90 \mathrm{~min}$. All assays were carried out under yellow light and in the presence of negative (dimethyl sulfoxide DMSO solvent, $5 \mu \mathrm{L} /$ plate) and positive (4-nitroquinoline oxide, $0.5 \mu \mathrm{g} / \mathrm{plate}$, CASRN. 56-57-5, and 2-aminofluorene, $1 \mu \mathrm{g} / \mathrm{plate}$, CASRN. 153-78-6, from Sigma-Aldrich, St. Louis, MO, USA) controls. Plates were incubated in the dark at $37^{\circ} \mathrm{C}$ for $72 \mathrm{~h}$, after which time revertants were counted. The sample was considered positive when a mutagenesis value of at least twice the negative value, a significant ANOVA $(\mathrm{p}<0.05)$ and a positive dose-response rate $(p<0.05)$ were observed. The results of the different assays were analyzed via the SALANAL program (Salmonella Assay Analysis, version 1.0, Integrated Laboratory Systems of Research Triangle Institute, RTP, North Carolina, USA). 
The choice between linear regression and the Bernstein model [19] was made to allow the elimination of data for doses outside the linear portion of the doseresponse curve. Positive results were interpreted as presenting significant mutagenicity, and were expressed as the number of revertants per volume of air sampled $\left(\mathrm{rev} / \mathrm{m}^{3}\right)$, i.e. rev/ $\mu \mathrm{g}$ multiplied by EOM in $\mu \mathrm{g} / \mathrm{m}^{3}$. In the cytotoxicity test, the solution containing the sample and the bacterial culture (100-200 cells) were plated on nutrient agar plates and incubated at $37^{\circ} \mathrm{C}$ for $24 \mathrm{~h}$ and the surviving colonies were counted. The sample was considered cytotoxic if the percentage of surviving cells was less than $60 \%$ of the negative control after one or more doses [14].

\section{Results}

\subsection{Airborne particulate matter}

Table 1 shows the air volume $\left(\mathrm{m}^{3}\right)$, PM2.5 concentration $\left(\mu \mathrm{g} / \mathrm{m}^{3}\right)$, and extractable organic matter $(\mathrm{EOM})\left(\mu \mathrm{g} / \mathrm{m}^{3}\right)$ of the samples analyzed from the different sites between November 2010 and May 2011.

The highest average PM2.5 values were detected at site $3\left(54\right.$ to $\left.141 \mu \mathrm{g} / \mathrm{m}^{3}\right)$, followed by site 2 (27 to $\left.38 \mu \mathrm{g} / \mathrm{m}^{3}\right)$ and site 1 (25 and $\left.34 \mu \mathrm{g} / \mathrm{m}^{3}\right)$ (Table 1$)$.

Table 1: Collection sites, air volume, PM $2.5 \mu \mathrm{m}$ concentration and extractable organic matter (EOM) of the samples analyzed.

\begin{tabular}{l|c|c|c|c}
\hline Site & Month & $\begin{array}{c}\text { Air Volume } \\
\left(\mathrm{m}^{3}\right) \pm \text { S.D. }\end{array}$ & $\begin{array}{c}\text { PM 2.5 } \mu \mathrm{m} \\
\left(\mu \mathrm{g} / \mathrm{m}^{3}\right) \pm \text { S.D. }\end{array}$ & $\begin{array}{c}\mathrm{EOM} \\
\left(\mu \mathrm{g} / \mathrm{m}^{3}\right)\end{array}$ \\
\hline 1 & Nov & $1567 \pm 112$ & $25 \pm 15$ & 8.62 \\
& Dec & $1538 \pm 25$ & $15 \pm 7$ & 1.46 \\
& Jan & $1568 \pm 50$ & $17 \pm 2$ & 13.89 \\
& Feb & $1538 \pm 12$ & $14 \pm 8$ & 0.35 \\
& Apr & $1530 \pm 11$ & $19 \pm 4$ & 0.68 \\
& May & $1524 \pm 66$ & $34 \pm 22$ & 4.19 \\
\hline 2 & Nov & $1552 \pm 9$ & $31 \pm 8$ & 8.70 \\
& Dec & $1536 \pm 39$ & $25 \pm 9$ & 3.90 \\
& Jan & $1568 \pm 50$ & $28 \pm 12$ & 6.22 \\
& Feb & $1580 \pm 38$ & $27 \pm 10$ & 10.92 \\
& Apr & $1519 \pm 31$ & $38 \pm 20$ & 3.21 \\
& May & $1490 \pm 49$ & $27 \pm 11$ & 10.73 \\
\hline 3 & Nov & $379 \pm 5$ & $74 \pm 24$ & 29.66 \\
& Dec & $442 \pm 10$ & $70 \pm 50$ & 49.20 \\
& Jan & $397 \pm 16$ & $68 \pm 20$ & 54.85 \\
& Feb & $473 \pm 67$ & $62 \pm 25$ & 1.58 \\
& Apr & $415 \pm 458$ & $141 \pm 44$ & 3.49 \\
& May & $458 \pm 47$ & $54 \pm 27$ & 3.16 \\
\hline $1-U E R$
\end{tabular}

1 - UERJ; 2 - Avenida Brasil; 3 - Rebouças tunnel. S.D. $=$ standard deviation. Airborne PM $2.5 \mu \mathrm{m}$ samples were collected for $24 \mathrm{~h}$ at sites 1 and 2 , and $6 \mathrm{~h}$ at site 3 . $6 \mathrm{~h}$ time filter saturation at site 3 . No collections in March. 


\subsection{Analysis of polycyclic aromatic hydrocarbons (PAHs)}

Figure 1 shows PAH concentrations, in $\mathrm{ng} / \mathrm{m}^{3}$, at the three sites during period II.
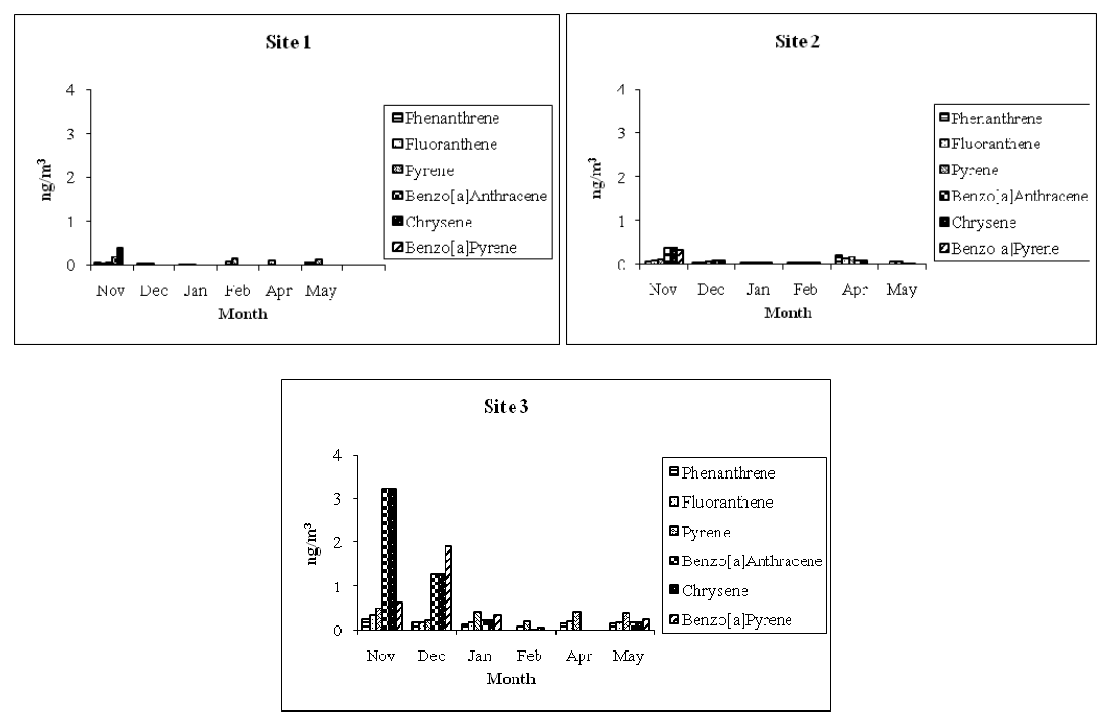

Figure 1: PAH concentrations in $\mathrm{ng} / \mathrm{m}^{3}$ of the three sites.

The highest concentrations of PAHs were at site 3, where benzo[a]anthracene $\left(3.23 \mathrm{ng} / \mathrm{m}^{3}\right)$ and chrysene $\left(3.23 \mathrm{ng} / \mathrm{m}^{3}\right)$ were predominant in November, and benzo[a]pyrene $\left(1.90 \mathrm{ng} / \mathrm{m}^{3}\right)$ was predominant in December.

\subsection{Analysis of nitro-polycyclic aromatic hydrocarbons (nitro-PAHs)}

Figure 2 shows the nitro-PAH concentrations, in $\mathrm{ng} / \mathrm{m}^{3}$, at the three sites.

Site 3 showed the highest concentrations of nitro-PAHs. The predominant nitro-PAHs at site 3 were: (November) nitro-pyrene $\left(2.52 \mathrm{ng} / \mathrm{m}^{3}\right)$, nitro-phenanthrene $\left(2.30 \mathrm{ng} / \mathrm{m}^{3}\right)$, nitro-acenaphthene $\left(2.10 \mathrm{ng} / \mathrm{m}^{3}\right)$, nitroacenaphthylene $\left(2.07 \mathrm{ng} / \mathrm{m}^{3}\right)$, nitro-anthracene $\left(2.06 \mathrm{ng} / \mathrm{m}^{3}\right)$ and nitro-fluorene $\left(1.97 \mathrm{ng} / \mathrm{m}^{3}\right)$;(December) nitro-anthracene $\left(1.56 \mathrm{ng} / \mathrm{m}^{3}\right)$, nitro-phenanthrene $\left(1.46 \mathrm{ng} / \mathrm{m}^{3}\right)$ and nitro-fluorene $\left(1.39 \mathrm{ng} / \mathrm{m}^{3}\right)$; (January) nitrobenzo[k]fluoranthene $\left(2.28 \mathrm{ng} / \mathrm{m}^{3}\right)$, nitro-acenaphthylene $\left(2.20 \mathrm{ng} / \mathrm{m}^{3}\right)$, nitro-fluorene $\left(1.87 \mathrm{ng} / \mathrm{m}^{3}\right)$, nitro-phenanthrene $\left(1.86 \mathrm{ng} / \mathrm{m}^{3}\right)$ and nitroanthracene $\left(1.71 \mathrm{ng} / \mathrm{m}^{3}\right) ;\left(\right.$ February) nitro-benzo[a]pyrene $\left(1.86 \mathrm{ng} / \mathrm{m}^{3}\right)$, nitro-benzo[b]fluoranthene $\left(1.55 \mathrm{ng} / \mathrm{m}^{3}\right)$ and nitro-chrysene $\left(1.48 \mathrm{ng} / \mathrm{m}^{3}\right)$; (April) nitro-benzo[b]fluoranthene $\left(2.08 \mathrm{ng} / \mathrm{m}^{3}\right)$ and nitro-phenanthrene $\left(1.93 \mathrm{ng} / \mathrm{m}^{3}\right)$; (May) nitro-phenanthrene $\left(1.73 \mathrm{ng} / \mathrm{m}^{3}\right)$, nitro-fluorene $\left(1.93 \mathrm{ng} / \mathrm{m}^{3}\right)$ and nitro-anthracene $\left(1.34 \mathrm{ng} / \mathrm{m}^{3}\right)$.

The predominant nitro-PAHs at site 2 were: (November, January and February) nitro-chrysene $\left(0.57-0.84 \mathrm{ng} / \mathrm{m}^{3}\right)$ and nitro-benzo[b]fluoranthene 

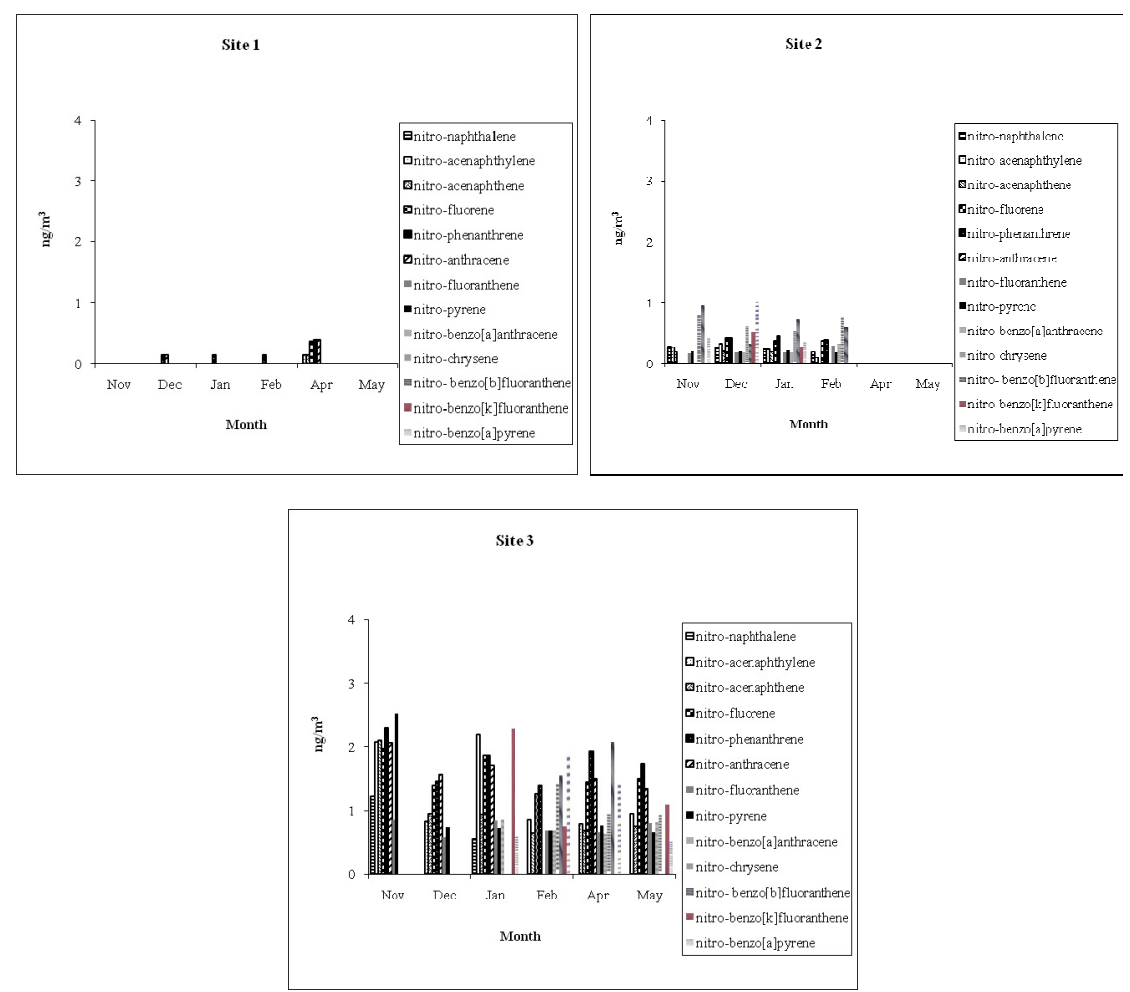

Figure 2: Nitro-PAH concentrations in $\mathrm{ng} / \mathrm{m}^{3}$ of the three sites.

(0.61-0.96 ng/ $\left.\mathrm{m}^{3}\right)$; (December) nitro-chrysene $\left(0.65 \mathrm{ng} / \mathrm{m}^{3}\right)$ and nitrobenzo[a]pyrene $\left(1.04 \mathrm{ng} / \mathrm{m}^{3}\right)$. No nitro-PAHs were detected at site 2 in April or May.

The predominant nitro-PAHs at site 1 were: (December) nitro-phenanthrene $\left(0.14 \mathrm{ng} / \mathrm{m}^{3}\right)$ and nitro-anthracene $\left(0.15 \mathrm{ng} / \mathrm{m}^{3}\right)$; (January) nitro-phenanthrene $\left(0.14 \mathrm{ng} / \mathrm{m}^{3}\right)$; (February) nitro-phenanthrene $\left(0.14 \mathrm{ng} / \mathrm{m}^{3}\right)$; (April) nitrophenanthrene $\left(0.39 \mathrm{ng} / \mathrm{m}^{3}\right)$, nitro-anthracene $\left(0.39 \mathrm{ng} / \mathrm{m}^{3}\right)$ and nitro-fluorene $\left(0.37 \mathrm{ng} / \mathrm{m}^{3}\right)$. No nitro-PAHs were detected at site 1 in November or May.

\subsection{Salmonella/microsome assay}

Table 2 shows the mutagenicity data for the organic extracts from airborne particulate matter in rev $/ \mathrm{m}^{3}$ during period II. Cytotoxic effects were not detected for any of the samples analyzed.

Mutagenic frameshift responses in the presence of metabolic activation were detected only at site 3 (November, December and May) (Table 2).

Mutagenic frameshift responses in the absence of metabolic activation were detected at site 1 (November, December and April), site 2 (December, January, February, April and May) and site 3 (November and April) (Table 2). 


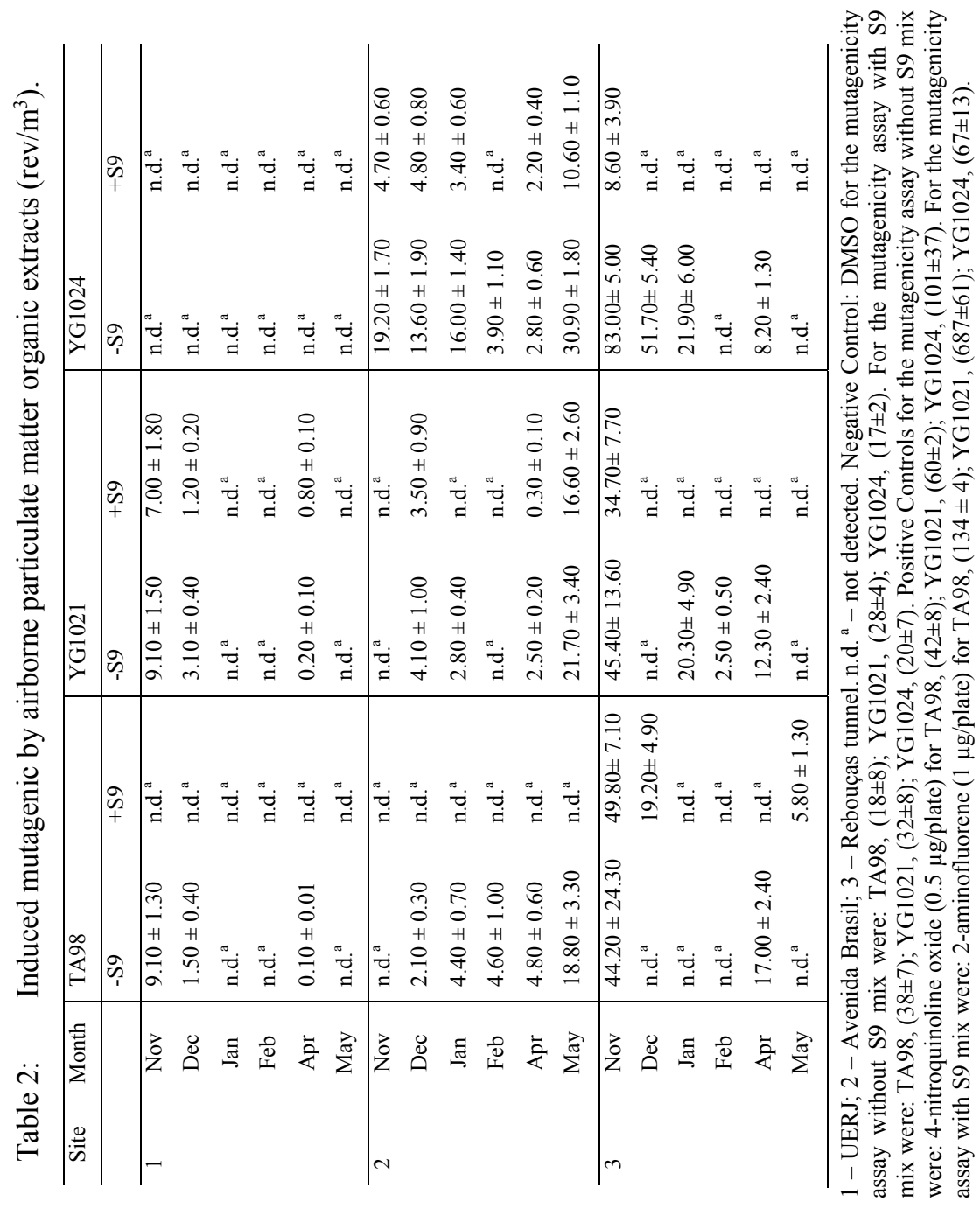


The presence of nitroarenes was detected at site 1 in November, December and April; at site 2 in December and May; and at site 3 in November, January and February. The presence of dinitroarenes and hydroxylamines was detected at site 2 in November, December, January and May, and at site 3 in November, December and January.

\section{Discussion}

The average PM2.5 concentrations at all three sites were higher during period II than recommended by the WHO (site $3: 54-141 \mu \mathrm{g} / \mathrm{m}^{3}$; site $2: 27-38 \mu \mathrm{g} / \mathrm{m}^{3}$; site 1: 25 and $34 \mu \mathrm{g} / \mathrm{m}^{3}$ ), which recommends a daily mean of up to $25 \mu \mathrm{g} / \mathrm{m}^{3}[11]$. Vehicle emissions are a major source of particles, especially in urban areas [20 22]. The fleet of vehicles in Rio de Janeiro has tripled in the last twenty years, and the high values of PM2.5 can be related to this fact [10]. Sites 2 and 3 are areas of the city that have heavy traffic, and they are the sites that yielded the highest average levels of PM2.5. Site 3 is a tunnel, and besides the heavy traffic it also lacks adequate ventilation, which could hamper the dispersion of pollutants.

High levels of PM2.5 were also detected during period I (site 3: 94$132 \mu \mathrm{g} / \mathrm{m}^{3}$; site $2: 26-60 \mu \mathrm{g} / \mathrm{m}^{3}$; site $1: 30-36 \mu \mathrm{g} / \mathrm{m}^{3}$ ) at these same sites [9, 10]. When comparing the two periods (July to October 2010 and November 2010 to May 2011), we observed higher PM2.5 values in period I. A study conducted from August 2010 to March 2011 in Porto Alegre, Brazil, detected high concentrations of PM2.5 in August [4]. The increased values of PM at this time of year can be related to the winter weather conditions. The reduction in PM2.5 values at site 3 during January and February 2011 (period II) may be related to the summer school vacations, during which time there are fewer vehicles on the roads.

PAHs are formed from the incomplete combustion of organic matter and may be introduced into the environment from several sources. Their main source in urban areas, according to Reisen and Arey [23], is exhaust gases from internal combustion engines, especially diesel [14]. Owing to their utility as tracers, it is essential to document their atmospheric abundance to identify the sources in different environments [24].

The highest PAH concentrations detected at site 3 are caused by vehicular emissions and restricted ventilation. These PAHs are classified according to their carcinogenicity by the International Agency for Research on Cancer [25]: benzo[a]pyrene is in Group 1 (carcinogenic to humans), and benzo[a]anthracene and chrysene are in Group 2B (possibly carcinogenic to humans).

Although site 2 has heavy traffic, it is in an area that has many dispersion factors, such as wind and rain, which could explain why its PAH levels are lower than at site 3 . When comparing the two periods, we observed similar PAH values at sites 1 and 2 [10]. However, in November (during Period II), only benzo[a]anthracene and chrysene were detected at site 1, and only benzo[a]pyrene was detected at site 2. Periods with high temperatures and photochemical decomposition are propitious for PAHs dispersal. Several studies 
that monitor levels of PAHs have detected a reduction in these pollutants during the summer [26-28].

Site 3 had the highest values for benzo[a]anthracene, chrysene and benzo[a]pyrene during period II (November and December). The increase in these PAHs may be related to gasoline and diesel vehicular emissions [29, 30].

Nitro-PAHs present in the atmosphere originate from primary sources, such as vehicle emissions, especially from diesel-fueled vehicles [31-33]. In addition, nitro-PAHs are also formed in the atmosphere via a reaction of their parent PAHs initiated by hydroxyl $(\mathrm{OH})$ radicals during the day and by nitrate $\left(\mathrm{NO}_{3}\right)$ radicals (in the presence of $\mathrm{NO}_{\mathrm{x}}$ ) during the night [33-35] and/or the heterogeneous gas-particle interaction of the parent PAHs adsorbed onto particles with nitrating agents [36]. Nitro-PAHs have $2.10^{5}$ times the mutagenic and ten times the carcinogenic potential of PAHs [33, 37].

In period I no nitro-PAH analysis was performed, which prevents a comparison between the two periods. Site 3 showed the highest concentrations of nitro-PAHs. This result may be related to vehicular emissions and inadequate ventilation. The nitro-PAH levels detected at site 3 were up to 21 times higher than in other tunnels: Allegheny Mountain $\left(0.12 \mathrm{ng} / \mathrm{m}^{3}\right.$ 1-nitropyrene) [38]; Baltimore Harbour $\left(0.34 \mathrm{ng} / \mathrm{m}^{3} 1\right.$-nitropyrene and $0.29 \mathrm{ng} / \mathrm{m}^{3}$ 9-nitroanthracene) [39] and Queensway $\left(0.56 \mathrm{ng} / \mathrm{m}^{3} \quad\right.$ 1-nitropyrene and $0.36 \mathrm{ng} / \mathrm{m}^{3} \quad 9$ nitroanthracene) [40].

Meanwhile, site 1 was found to have the lowest nitro-PAH values. This may be related to the lower automotive emissions than at the other two sites under study. The highest nitro-PAH values were at site 2, especially during the hottest months of the year. Similar nitro-PAH values were detected during the summer in the metropolitan area of Porto Alegre [33]. These results may be related to the interaction between PAHs and nitro compounds in photochemical smog.

All strains detected higher rev/ $/ \mathrm{m}^{3}$ in period I $[9,10]$ than in period II at all three sites. There was less rainfall in period I than in period II. This seasonal characteristic could lead to a concentration of pollutants and thereby increased values of rev $/ \mathrm{m}^{3}$. Increased mutagenic responses during the winter have been detected in several studies that evaluate the mutagenicity of PM seasonally [2, 4, 26]. Decreased levels of rev/ $\mathrm{m}^{3}$ were detected mainly in the rainy months (December 2010 to February 2011 - period II). Rain cleanses some particles from the atmosphere, but this does not mean that there is no further risk of exposure to contaminants associated with the particles that remain in the environment $[2,41,42]$.

For period I, mutagenic frameshift responses in the presence of metabolic activation were detected at all three sites [9, 10]. However for period II mutagenic frameshift responses in the presence of metabolic activation were detected only at site 3 . These results can be attributed to the presence of promutagens such as $\mathrm{PAH}$, resulting from intense vehicular emissions and inadequate ventilation in this tunnel.

Mutagenic frameshift responses in the absence of metabolic activation were detected at all the sites during periods I [9] and II. These results could indicate the predominance of direct-acting frameshift activity in the airborne particulate 
material. Several authors have recognized the contribution of nitrocompounds to direct frameshift mutagenicity in urban atmospheric samples, associating this capacity with the presence of PAH derivatives, such as mono- or dinitro PAHs $[3,4,12]$. The contribution of nitrocompounds to direct mutagenic activity was investigated through the Salmonella/microsome assay with specific strains YG1021 (pYG216) and YG1024 (pYG219), which over express highly active enzymes with a high sensitivity to nitrocompounds such as nitroarenes or dinitrorenes, hydroxylamines and aromatic amines [18]. In period I, nitroarenes and dinitroarenes were detected at all three sites [9, 10]. During period II, the presence of nitroarenes was also detected at all the sites, but dinitroarenes were only detected at sites 2 and 3. Nitroarenes and dinitroarenes result from direct emissions of diesel combustion and can be produced by atmospheric reactions of PAH with gaseous copollutants found in photochemical smog [43, 44]. Studies performed in the urban region of Porto Alegre detected a similar response during the hot season, when there is marked mutagenic activity due to the presence of mono and dinitroarene compounds in different sizes of atmospheric particles such as PTS, PM10 and PM2.5 [4, 45].

\section{Conclusion}

In conclusion, air quality in Rio de Janeiro is worsening as traffic becomes heavier. The data generated in this study show that in certain periods of the year, different levels of PAHs and nitroderivatives probably contribute to the airborne mutagenicity detected at different sites of Rio de Janeiro. However, less variation in the levels of PAHs and nitroderivatives was found in Rio de Janeiro than has been reported in other places where winter temperatures are lower. This may be attributed to the fact that the city of Rio de Janeiro does not have wide temperature fluctuations during the year.

\section{Acknowledgements}

We thank Fundação Carlos Chagas Filho de Amparo à Pesquisa do Estado do Rio de Janeiro (FAPERJ, 23/2008), Coordenação de Aperfeiçoamento de Pessoal de Nível Superior (CAPES) and Conselho Nacional de Desenvolvimento Científico e Tecnológico (CNPq) for their financial support, and the Rio de Janeiro city departments of education and transportation for their partnership in this work.

\section{References}

[1] Oh, S.M., Kim, H.R., Park, Y.J., Lee, S.Y. \& Chung, K.H., Organic extracts of urban air pollution particulate matter (PM2.5)-induced genotoxicity and oxidative stress in human lung bronchial epithelial cells (BEAS-2B cells). Mutation Research, 723(2), pp. 142-151, 2011. 
[2] Pereira, T.S., Beltrami, L.S., Rocha, J.A.V., Broto, F.P., Comellas, L.R., Salvadori, D.M.F. \& Vargas, V.M.F., Toxicogenetic monitoring in urban cities exposed to different airborne contaminants. Ecotoxicology and Environmental Safety, 90, pp. 174-182, 2013.

[3] Claxton, L.D., Matthews, P. \& Warren, S., The genotoxicity of ambient outdoor air, a review: Salmonella mutagenicity. Mutation Research, 567(2-3), pp. 347-399, 2004.

[4] De Brito, K.C.T., de Lemos, C.T., Rocha, J.A.V., Mielli, A.C., Matzenbacher, C. \& Vargas, V.M.F., Comparative genotoxicity of airborne particulate matter (PM2.5) using Salmonella, plants and mammalian cells. Ecotoxicology and Environmental Safety, 94, pp. 14-20, 2013.

[5] De Martinis, B.S., Kado, N.Y., Carvalho, L.R.F., Okamoto, R.A. \& Gundel, L.A., Genotoxicity of fractionated organic material in air borne particles from São Paulo, Brazil. Mutation Research, 446(1), pp. 83-94, 1999.

[6] Lewtas, J., Air pollution combustion emissions: characterization of causative agents and mechanisms associated with cancer, reproductive, and cardiovascular effects. Mutation Research, 636(1-3), pp. 95-133, 2007.

[7] Alerta Rio. Relatórios Anuais de Chuva. www0.rio.rj.gov.br /alertario/?page $\mathrm{id}=1110$.

[8] García-Suástegui, W.A., A., Huerta-Chagoya, K.L., Carrasco-Colín, M.M, Pratt, John, K., Petrosyan, P., Rubio, J., Poirier, M.C. \& Gonsebatt, M.E., Seasonal variations in the levels of PAH-DNA adducts in young adults living in Mexico City. Mutagenesis, 26(3), pp. 385-391, 2011.

[9] Rainho, C.R., Velho, A.M.A., Corrêa, S.M., Mazzei, J.L., Aiub, C.A.F. \& Felzenszwalb, I., Prediction of health risk due to polycyclic aromatic hydrocarbons present in urban air in Rio de Janeiro, Brazil. Genetics and Molecular Research, 12(3), pp. 3992-4002, 2013 a.

[10] Rainho, C.R., Corrêa, S.M., Mazzei, J.L., Aiub, C.A.F. \& Felzenszwalb, I., Genotoxicity of Polycyclic Aromatic Hydrocarbons and Nitro-Derived in Respirable Airborne Particulate Matter Collected from Urban Areas of Rio de Janeiro (Brazil). BioMed Research International, 2013, pp. 1-9, 2013b.

[11] WHO (World Health Organization), Health Risks of Particulate Matter From Long Range Transboundary Air Pollution, Copenhagen, 99 pages, 2006.

[12] Vargas, V. M. F., Horn, R.C., Guidobono, R.R., Mittelstaedt, A.B. \& de Azevedo, I.G., Mutagenic activity of airborne particulate matter from the urban area of Porto Alegre, Brazil. Genetics and Molecular Biology, 21(2), pp. 247-253, 1998.

[13] Coronas, M.V., Horn, R.C., Ducatti, A., Rocha, J.A.V. \& Vargas, V.M.F., Mutagenic activity of airborne particulate matter in a petrochemical industrial area. Mutation Research, 650(2), 196-201, 2008. 
[14] Pereira, T.S., Gotor, G.N., Beltrami L.S., et al., Salmonella mutagenicity assessment of airborne particulate matter collected from urban areas of Rio Grande do Sul State, Brazil, differing in anthropogenic influences and polycyclic aromatic hydrocarbon levels. Mutation Research, 702(1), pp. 78-85, 2010.

[15] Corrêa, S.M. \& Arbilla, G., A two-year monitoring program of aromatic hydrocarbons in Rio de Janeiro downtown area. Journal of the Brazilian Chemical Society 18(3), pp. 539-543, 2007.

[16] Kado, N.Y., Guirguis, G.N., Flessel, C.P., Chan, R.C., Chang, K. \& Wesolowski, J.J., Mutagenicity of fine $(<2.5 \mu \mathrm{m})$ airborne particles: diurnal variation in community air determined by a Salmonella micro preincubation (microsuspension) procedure. Environmental Mutagenesis, 8(1), pp. 53-66, 1986.

[17] Maron, D.M. \& Ames, B.N., Revised methods for the Salmonella mutagenicity test. Mutation Research, 113(3-4), 173-215, 1983.

[18] Watanabe, M., Ishidate, M. \& Nohmi, T., A sensitive method for the detection of mutagenic nitroarenes: construction of nitroreductaseoverproducing derivatives of Salmonellatyphimurium strains TA98 and TA100. Mutation Research, 216(4), pp. 211-220, 1989.

[19] Bernstein L., Kaldor, J., McCann, J. \& Pike, M.C., An empirical approach to the statistical analysis of mutagenesis data from the Salmonella test. Mutation Research, 97(4), pp. 267-281, 1982.

[20] Weijers, E.P., Khlystov, A.Y., Kos, G.P.A. \& Erisman, J.W., Variability of particulate matter concentrations along roads and motorways determined by a moving measurement unit. Atmospheric Environment, 38(19), pp. 2993-3002, 2004.

[21] Gertler, A.W., Diesel vs. gasoline emissions: does PM from diesel or gasoline vehicles dominate in the US? Atmospheric Environment, 39(13), pp. 2349-2355, 2005.

[22] Onat, B. \& Stakeeva, B., Personal exposure of commuters in public transport to PM2.5 and fine particle counts. Atmospheric Pollution Research, 4, pp. 329-335, 2013.

[23] Reisen, F. \& Arey, J., 2005. Atmospheric reactions influence seasonal $\mathrm{PAH}$ and nitro-PAH concentrations in the Los Angeles Basin. Environmental Science Technology, 39(1), pp. 64-73, 2005.

[24] Rajput, P., Sarin, M. \& Kundu, S.S., Atmospheric particulate matter (PM2.5), EC, OC, WSOC and PAHs from NE-Himalaya: abundances and chemical characteristics. Atmospheric Pollution Research, 4(2), pp. 214 221, 2013.

[25] IARC, International Agency for Research on Cancer, Monographs on the evaluation of carcinogenic risks to humans. Some non-heterocyclic aromatic hydrocarbons and some related exposures, vol. 92, 1-18, Lyon, 2005.

[26] Piekarska, K. \& Karpińska-Smulikowska, J., Mutagenic Activity of Environmental Air Samples from the Area of Wrocław, Poland. Polish Journal of Environmental Studies, 16(5), pp. 745-752, 2007. 
[27] Dallarosa, J., Teixeira, E.C., Meira, L. \& Wiegand, F., Study of the chemical elements and polycyclic aromatic hydrocarbons in atmospheric particles of PM10 and PM2.5 in the urban and rural areas of South Brazil. Atmospheric Research, 89(1-2), pp. 76-92, 2008.

[28] Zaciera, M., Kurek, J., Dzwonek, L., Feist, B. \& Jedrzejczak, A., Seasonal variability of PAHs and NITRO-PAHs concentrations in total suspended particulate matter in ambient air of cities of Silesian Voivodeship. Environment Protection Engineering 38(1), pp. 45-50, 2012.

[29] Cadle, S.H., Mulawa, P.A., Hunsanger, E.C. et al., Composition of lightduty motor vehicle exhaust particulate matter in the Denver, Colorado area. Environmental Science and Technology, 33(14), pp. 2328-2339, 1999.

[30] He, L.Y., Hu, M., Huang, X.F., Zhang, Y.H., Yu, B.D. \& Liu, D.Q., Chemical characterization of fine particles from on-road vehicles in the Wutong tunnel in Shenzhen China. Chemosphere, 62(10), pp. 1565-1573, 2006.

[31] Nielsen, T., Reactivity of polycyclic aromatic hydrocarbons towards nitrating species. Environmental Science \& Technology, 18(3), pp. 157163, 1984.

[32] Bamford, H.A. \& Baker, J.E., Nitro-polycyclic aromatic hydrocarbon concentrations and sources in urban and suburban atmospheres of the MidAtlantic region. Atmospheric Environment 37(15), pp. 2077-2091, 2003.

[33] Teixeira, E.C., Garcia, K.O., Meincke, L. \& Leal, K.A., Study of nitropolycyclic aromatic hydrocarbons in fine and coarse atmospheric particles. Atmospheric Research, 101(3), pp. 631-639, 2011.

[34] Atkinson, R., Arey, J., Atmospheric chemistry of gas phase polycyclic aromatic hydrocarbons: formation of atmospheric mutagens. Environmental Health Perspectives, 102(4), pp. 117-126, 1994.

[35] Söderström, H., Hajslova, J., Kocourek, V., Siegmund, B., Kocan, A., Obiedzinski, M.W., Tysklind, M. \& Bergqvist, P., PAHs and nitrated PAHs in air of Five European countries determined using SPMDs as passive samplers. Atmospheric Environment, 39(9), pp. 1627-1640, 2005.

[36] Feilberg, A.B., Poulsen, M.W., Nielsen, T. \& Skov, H., Occurrence and sources of particulate nitro-polycyclic aromatic hydrocarbons in ambient air in Denmark. Atmospheric Environment, 35(2), pp. 353-366, 2001.

[37] Durant, J.L., Busby, W.F., Lafleur, A.L., Penman, B.W. \& Crespi, C.L., Human cell mutagenicity of oxygenated, nitrated and unsubstituted polycyclic aromatic hydrocarbons associated with urban aerosols. Mutation Research, 371(3-4), pp. 123-157, 1996.

[38] Gorse Jr., R.A., Riley, T.L., Ferris, F.C., Pero, A.M. \& Skewes, L.M., 1-nitropyrene concentration and bacterial mutagenicity in on-road vehicle particulate emissions. Environmental Science and Technology, 17(4), pp. 198-202, 1983.

[39] Benner, Jr. B.A., Mobile sources of polycyclic aromatic hydrocarbons (PAH) and nitro-PAH: a roadway tunnel study, USA, University of Maryland, 1988. 
[40] Dimashki, M., Harrad, S. \& Harrison, R.M., Measurements of nitro-PAH in the atmospheres of two cities. Atmospheric Environment, 34(15), pp. 2459-2469, 2000.

[41] Amador-Munõz, O., Delgado-Rodriguez, A., Villalobos-Pietrini, R., OrtizMartello, R., Díaz-González, G., Bravo-Cabrera, J.L. \& Gómez-Arroyo, S., Partículas suspendidas hidrocarburosaromáticos policíclicos y mutagenicidad en el suroeste dela Ciudad de México. Revista Internacional Contaminación Ambiental, 17(4), pp. 193-204, 2001.

[42] Rinaldi, M.C.S., Domingos, M., Dias, A.P.L, Esposito, J.B.N. \& Pagliuso, J.D., Leaves of Lolium multiflorum "Lema' and tropical tree species as biomonitors of polycyclic aromatic hydrocarbons. Ecotoxicology and Environmental Safety, 79(2), pp. 139-147, 2012.

[43] Pitts Jr., J.N., On the trail of atmospheric mutagens and carcinogens: a combined chemical/microbiological approach. American Zoologist, 25(2), pp. 415-431, 1985.

[44] Sato, M. I. Z., Umbuzeiro, G.A., Coimbrão, C.A. et al., Mutagenicity of airborne particulate organic material from urban and industrial areas of São Paulo, Brazil. Mutation Research, 335(3), pp. 317-330, 1995.

[45] Vargas, V.M.F., Brito, K.C.T. \& Coronas, M.V., Genetic biomarkers applied to environmental air quality: ecological and human health aspects. In: Mazzeo, N. A. (Ed.), Air Quality Monitoring, www.intechopen.com/books/air-quality-monitoring-assessment-andmanagement, 2011. 